\title{
EVALUATION OF POWERTOP® AS GROWTH ENHANCER OF NILE TILAPIA (Oreochromis siloticus) FINGERLINGS AT DIFFERENT STOCKING WEIGHTS
}

\author{
M.S. Ayyat ${ }^{1}$, Hemat K. Mahmoud ${ }^{1}$ and A. M A El-Hais ${ }^{2}$ \\ 1- Department of Animal Production, Faculty of Agriculture, Zagazig University, Egypt, 2- Department of \\ Animal Production, Faculty of Agriculture, Tanta University, Egypt
}

\section{SUMMARY}

This study was performed to estimate the effects of fish initial live body weight (3.5 and $35 \mathrm{~g} /$ fish) and probiotic, powertop ${ }^{\circledR}$ extract ( $\beta$-glucan, formic acid, lactic acid, propionic acid and silicate) at 0.5 and $1.0 \mathrm{~g}$ of powertop ${ }^{\circledR} / \mathrm{kg}$ diet on growth performance, feed utilization, body composition and some blood components of Nile tilapia (Oreochromis niloticus) fingerlings. The stocking weight, powertop ${ }^{\circledR}$ supplementation and their interaction had significant $(P<0.001$ or 0.01$)$ effects on growth performance parameters while the survival rate was insignificantly affected. Also both of it(what) and its interaction had no significant influence on dry matter, crude protein and ash contents of whole body composition. Fish group supplemented with $0.5 \mathrm{~g}$ powertop ${ }^{\circledR} / \mathrm{kg}$ diet recorded the highest $(P<0.05)$ value for ether extract of fish body composition. Powertop ${ }^{\circledR}$ supplementation, stoking weight and their interaction had no adverse effects on blood parameters and liver activity. Superior return from body gain and final profit were obtained in the fish group fed diet supplemented with $0.5 \mathrm{~g} / \mathrm{kg}$ diet powertop ${ }^{\circledR}$ and reared at low stocking weight. It was concluded that, Powertop ${ }^{\circledR}$ probiotic improved the growth performance, body composition and some blood motilities of Nile tilapia (Oreochromis niloticus) fingerlings. Therefore, it can be used as growth enhancer in Nile tilapia fingerlings diets.

\section{Keywords: Nile tilapia, weight, powertop ${ }^{\circledR}$, performance, body composition and blood components.}

\section{INTRODUCTION}

Probiotics are live bacteria, that have received some attention in aquaculture, reported a decline in mortality rate (El-Haroun et al., 2006), improved the ability to inhibit other organisms (Burgents et al., 2004), improved fish growth rate, feed conversion (El-Haroun et al., 2006), improved making of digestive enzyme activity and polyamines (Tovar et al., 2002). Also, probiotics support good health for fish by invigorating the immune system against infections, alleviate lactose intolerance, dropping blood cholesterol levels (Salminen et al., 2004 and Lara-Flores and Aguirre-Guzman, 2009).

Probiotic bacteria must be non-pathogenic and non-toxic (Vine et al., 2004). Lactic acid is one of the compounds which is able to inhibit the growth of harmful microorganisms (Ringø and Gatesoupe, 1998 and Gatesoupe, 1999). Maurilio et al. (2002) have exposed that the utilize of bacteria Streptococcus faecium, Lactobacillus acidophilus and yeast Saccharomyces cerevisiae as probiotics in tilapia fish diets improved growth performance, and decreased the effects of stress factors.

Among the most used propionic acids that make sure a stable product free of pathogenic microorganisms (Morales-Ulloa and Oetterer, 1995). Also, the formic acid can be used alone or with additional fatty acids as a citric acid to reduce the cost and be more effective antimicrobial activity, besides providing a better stability to the material (Fagbenro and Fasakin, 1996 and Gao et al., 1992).

In aquaculture, $\beta$-glucan has been shown to promote disease resistance (Lauridsen and
Buchmann, 2010) and to enhance the immune reaction in various fish species such as common carp (Cyprinus carpio), sea bass (Dicentrarchus labrax), and rainbow trout (Dalmo and Bøgwald, 2008). However the beneficial effects of $\beta$-glucan that has been report by several authors (Rodriguez et al., 2009 and Guselle et al., 2007) appear to be strongly dependent on dose, duration of action and route of administration. Dalmo and Seljelid, (1995) showed that, $\beta$-glucans as one of its contents is wide spread in nature, plant, algae, bacteria, yeast and mushrooms. $\beta$-glucans are non-antigenic in animals, but have been implicated to be powerful activators of non-specific defense mechanisms in a wide range of fishes (Kumari and Sahoo, 2006 and Guselle et al., 2007). Forms of $\beta$-glucan also, derived from yeast mainly comprise D-glucose units with $\beta$-1,3-linkages and side-chains of D-glucose at position six. These homopolysaccharides are denominated as b-1,3/ 1,6glucans and have been shown to reduce the susceptibility to infection (Chen and Seviour, 2007, and Dalmo and Bøgwald, 2008).

Ayyat et al. (2014) reported that superlative growth rate and feed conversion were recorded in the fish group fed a cocktail of three bacteria (Lactobacillus acidophilus, Streptococcus thermophilus and Bifidobacterium bifidum). Profit margin increased in fish groups fed diets inoculated with probiotics. Supplementation with Lactobacillus acidophilus, Bifidobacterium bifiduim, and the threebacterium cocktail were most effective in eliminating mortality in an A. hydrophila challenge.

Therefore, the objectives of the current study are to satisfy and to establish the effects of fish initial 
live body weight and probiotics; powertop extract ( $\beta$ glucan, formic acid, lactic acid, propionic acid and silicate); on growth performance, feed utilization, body composition and some blood parameters of Nile tilapia (O. niloticus).

\section{MATERIAL AND METHODS}

\section{Experimental design and diets:}

Nile tilapia (Oreochromis niloticus) used in the present study were obtained from the Central Laboratory for Aquaculture Research at Abbassa, Abou-Hammad, Sharkia, Egypt and used for experimental period of 12 weeks (84 days) ONLY ONE OF THEM from June to September, 2014. The experiment was carried out at the Wet Laboratory, Animal Production Department, Faculty of Agriculture, Zagazig University, Egypt.

All of the experimental fish groups were fed on a basal pelleted diet consisting of fish meal, soybean meal, corn, wheat bran, wheat flour, goluten (60\%), sunflower oil minerals mixture and vitamin mixture (Table 1). Diets were formulated to contain about $31.22 \%$ crude protein and $4267.5 \mathrm{Kcal} / \mathrm{Kg}$ gross energy. Diets were offered to fish three times daily $(8.00,12.00$ and 15.00$)$ in equal proportions, six days a week for a period of 12 weeks at a rates of 3 and $5 \%$ of fish biomass daily for tilapia fry and fingerlings, respectively. Quantity of the additional feed was re-adjusted biweekly according to the increase in fish body weight. Fresh tap water was stored in fiberglass tanks for $24 \mathrm{~h}$ under aeration for dechlorination and half of all aquaria were replaced every two days. Air pebbles were used for aerating the aquaria water. Feces were disinterested daily by siphoning. Fish from each replicate were weighted at the start of the experiment, counted and weighted every two weeks throughout the experimental period (12 weeks).

Table 1. Ingrediants and proximate analysis of experimental diet






\section{Chemical analysis:}

Proximate analyses were done for diet ingredients and fish sample at the end of the experiment according to standard methods (AOAC, 1995) for dry matter, crude protein, ether extract, crude fiber and ash. Gross energy (GE) stuffing of the experimental diet and fish samples were calculated by using factors of $5.65,9.45$ and $4.22 \mathrm{kcal} / \mathrm{g}$ of protein, lipid and carbohydrates, respectively (NRC, 2011).

The body composition crude protein and ether extract content of experimental tilapia fish (Fry and fingerlings) fed on experimental diet with or without powertop ${ }^{\circledR}$ supplementations were determined using Kjeldahl and Soxhlet apparatu, respectively.

\section{Hematological parameters}

Blood samples were collected at the end of experiment, fry in each aquarium was weighed and 5 fry were taken at random for blood analysis. Heparinized syringes were used to collect the blood samples from fish caudal vein. Samples were used to measure the hemoglobin $(\mathrm{Hb})$ content using a commercial kit (Diamond Diagnostic, Egypt), was measured according to the methods of Stoskopf (1993). Total erythrocyte (RBCs), platelets and leukocyte (WBCs) counts were determined by using an Ao Bright-Line Haemocytometer (Neubauer improved, Precicolor HBG, Germany) according to the methods described by Jain (1993). Other blood samples for serum separation were collected without the addition of anticoagulants and then were centrifuged at $4000 \mathrm{rpm}$ for $20 \mathrm{~min}$. to make separation of plasma for determining plasma total protein (Tietz, 1990). The activity of alanine aminotransferase (ALT) and aspartate aminotransferase (AST) were estimated according to Young (1990).

\section{Measurements of growth and feed utilization parameters:}

Fish were weighed to the nearest $0.1 \mathrm{~g}$ at the beginning of the experiment and every 15 days and the amount of feed given was re-adjusted in accordance with the new measured biomass. The specific growth rate was calculated according to Laird and Needham (1988) by following equation: 100 (Ln final mean body weight - Ln initial mean body weight)/time intervals (days). The feed conversion ratio is expressed as the proportion of dry food fed required per unit live weight gain of fish according to Berger and Halver (1987).

\section{Profitable evaluation:}

Profitable evaluation was calculated as reported by Ayyat (1991): Final margin (profit) = Returns from body gain in weight - Feed cost. Other overhead costs were assumed constant. Price of one $\mathrm{kg}$ of diet was 4.10 LE (Egyptian pound $=0.113$ US dollar) and price of selling of one $\mathrm{kg}$ live body weight of fish was 14.0 LE. Relative margin $=$ Final margin $\mathrm{X}$ Survival rate
Analysis of variance for data was accomplished using the SAS General Liner Models Procedure (SAS, 2002). The effects of initial body weight and probiotic supplementation were statistically analyzed by factorial analysis of variance (2X3) (Snedecor and Cochran 1982) according the following statistical model: $\mathrm{Y}_{\mathrm{ijk}}=\mu+\mathrm{W}_{\mathrm{i}}+\mathrm{P}_{\mathrm{j}}+\mathrm{WP}_{\mathrm{ij}}+\mathrm{e}_{\mathrm{ijk}}$, where: $\mathrm{Y}_{\mathrm{ijk}}$ is an observation, $\mu$ is the overall mean, $\mathrm{W}_{\mathrm{i}}$ is the fixed effect of initial body weight $(\mathrm{i}=1 \ldots 2), \mathrm{P}_{\mathrm{j}}$ is the fixed effect of probiotic as power treatments $(\mathrm{j}=1 \ldots 3)$, $\mathrm{WP}_{\mathrm{ij}}$ is the interaction effect of initial body weight and powertop ${ }^{\circledR}$ treatments and $\mathrm{e}_{\mathrm{ijk}}$ is random error. Means were tested for significant differences by using Duncan's multiple range test (Duncan, 1955). All percentage and ratios were transformed to arc sin values previous to analysis (Zar 1984).

\section{RESULTS AND DISCUSSION}

No clear effect of fish initial live body weight and probiotic on the water quality in the all experimental groups, was observed. During the whole experimental period water-quality parameters averaged water temperature was $27.8 \pm 0.9{ }^{\circ} \mathrm{C}$, dissolved oxygen was $5.6 \pm 0.7 \mathrm{mg} / \mathrm{l}$, total ammonia was $0.19 \pm 0.12 \mathrm{mg} / \mathrm{l}$, nitrite was $0.07 \pm 0.03 \mathrm{mg} / \mathrm{l}$ and $\mathrm{pH}$ was $8.4 \pm 0.3$. Ranges of water quality parameters were within the acceptable ranges required for normal growth of tilapia as mentioned by Boyd (1990).

\section{Growth performance and feed utilization:}

The results obtainable in Table (2) show that stocking weight, powertop ${ }^{\circledR}$ supplementation and their interaction had significant $(\mathbf{P}<\mathbf{0 . 0 0 1}$ or $\mathbf{0 . 0 1})$ effects on growth performance studied except survival rate was insignificantly affected.

The best values of specific growth rate and feed conversion (2.57 and 1.37, respectively) were recorded with Nile tilapia stocked at low initial body weight. Final live body weight, daily growth rate and daily feed intake increased as affected by increasing stocking weight, while feed conversing retreated. Daily growth rate was increased by $60.6 \%$ in fish group stocked at higher initial body weight, while feed conversion was declined by $44.2 \%$.

The most excellent results in final weight, daily weight gain, specific growth rate and feed conversion ratio were observed in fish group fed on a diet supplemented with $0.5 \mathrm{~g}$ powertop ${ }^{\circledR}$ as compared with others fish groups. Daily growth rate increased by 47.1 and $29.4 \%$, respectively in fish group fed diets supplemented with 0.5 and $1.0 \mathrm{~g}$ powertop ${ }^{\circledR} / \mathrm{kg}$ diet, also feed conversion improved by 17.4 and $12.6 \%$, respectively.

Regarding to the results interaction between initial body weight of tilapia fry and powertop ${ }^{\circledR}$ supplementation, fish group fed diet supplemented with $0.5 \mathrm{~g}$ powertop ${ }^{\circledR}$ and reared at high stocking body weight had the preferable values of growth performance and best feed conversion.

\section{Statistical analysis:}


Table 2. Effect of stocking weight, Powertop ${ }^{\circledR}$ supplementation and their interaction on Nile tilapia performance and feed utilization.

\begin{tabular}{|c|c|c|c|c|c|c|c|c|}
\hline Items & $\begin{array}{c}\text { Initial } \\
\text { weight (g) }\end{array}$ & $\begin{array}{c}\text { Final } \\
\text { weight } \\
\text { (g/fish) }\end{array}$ & $\begin{array}{c}\text { Daily } \\
\text { weight } \\
\text { gain } \\
\text { (g/fish) }\end{array}$ & $\begin{array}{l}\text { Specific } \\
\text { growth } \\
\text { rate, } \\
\text { SGR (\%/ } \\
\text { day) }\end{array}$ & $\begin{array}{c}\text { Relative } \\
\text { growth rate, } \\
\text { RGR (\%) }\end{array}$ & $\begin{array}{c}\text { Daily Feed } \\
\text { Intake } \\
\text { (g/fish) }\end{array}$ & $\begin{array}{c}\text { Feed } \\
\text { conversion } \\
\text { (g food/ } \\
\text { g gain) }\end{array}$ & $\begin{array}{l}\text { Survival } \\
\text { rate }(\%)\end{array}$ \\
\hline \multicolumn{9}{|c|}{$\begin{array}{l}\text { Effect of fish stocking weight } \\
\text { Low stocking }\end{array}$} \\
\hline $\begin{array}{l}\text { weight }\left(\mathrm{W}_{1}\right) \\
\text { High stocking }\end{array}$ & $3.57 \pm 0.02$ & $31.19 \pm 1.65$ & $0.33 \pm 0.02$ & $2.57 \pm 0.06^{\mathrm{a}}$ & $158.21 \pm 2.00^{\mathrm{a}}$ & $0.45 \pm 0.01$ & $1.37 \pm 0.04$ & $92.22 \pm 2.78$ \\
\hline weight $\left(\mathrm{W}_{2}\right)$ & $35.27 \pm 0.06$ & $79.49 \pm 2.20$ & $0.53 \pm 0.03$ & $0.96 \pm 0.03^{b}$ & $76.70 \pm 2.49^{\mathrm{b}}$ & $1.48 \pm 0.02$ & $2.86 \pm 0.11$ & $98.89 \pm 1.11$ \\
\hline Significance & $* * *$ & $* * *$ & $* * *$ & $* * *$ & $* * *$ & $* * *$ & $* * *$ & NS \\
\hline \multicolumn{9}{|c|}{ Effect of dietary probiotic supplementation } \\
\hline $\begin{array}{l}\text { Control }\left(T_{1)}\right. \\
0.5 \text { g powertop } ®\end{array}$ & $19.44 \pm 7.12$ & $48.19 \pm 10.27^{\mathrm{c}}$ & $0.34 \pm 0.04^{\mathrm{c}}$ & $1.59 \pm 0.34^{\mathrm{c}}$ & $109.06 \pm 18.73^{\mathrm{c}}$ & $0.89 \pm 0.22^{\mathrm{c}}$ & $2.39 \pm 0.40^{\mathrm{a}}$ & $95.00 \pm 3.42$ \\
\hline $\begin{array}{l}\left(\mathrm{T}_{2}\right) \\
1.0 \text { g powertop } \AA\end{array}$ & $19.37 \pm 7.08$ & $61.22 \pm 11.01^{\mathrm{a}}$ & $0.50 \pm 0.05^{\mathrm{a}}$ & $1.92 \pm 0.38^{\mathrm{a}}$ & $124.19 \pm 18.11^{\mathrm{a}}$ & $1.02 \pm 0.24^{\mathrm{a}}$ & $1.92 \pm 0.30^{\mathrm{c}}$ & $96.67 \pm 2.11$ \\
\hline$\left(\mathrm{T}_{3}\right)$ & $19.44 \pm 7.07$ & $56.61 \pm 11.13^{\mathrm{b}}$ & $0.44 \pm 0.05^{\mathrm{b}}$ & $1.79 \pm 0.35^{\mathrm{b}}$ & $119.12 \pm 17.85^{b}$ & $0.98 \pm 0.23^{b}$ & $2.04 \pm 0.30^{\mathrm{b}}$ & $95.00 \pm 3.42$ \\
\hline Significance & NS & $* * *$ & $* * *$ & $* * *$ & $* * *$ & $* * *$ & $* * *$ & NS \\
\hline \multicolumn{9}{|c|}{ The interaction effect of stocking weight and dietary probiotic supplementation } \\
\hline $\mathbf{W}_{1} * \mathbf{T}_{1}$ & $3.53 \pm 0.01$ & $25.24 \pm 0.27^{\mathrm{f}}$ & $0.26 \pm 0.00^{\mathrm{f}}$ & $2.34 \pm 0.01^{\mathrm{b}}$ & $150.92 \pm 0.34^{\mathrm{c}}$ & $0.39 \pm 0.01^{\mathrm{f}}$ & $1.50 \pm 0.03^{\mathrm{c}}$ & $90.00 \pm 5.77$ \\
\hline $\mathbf{W}_{1} * \mathbf{T}_{2}$ & $3.55 \pm 0.03$ & $36.61 \pm 0.23^{\mathrm{d}}$ & $0.39 \pm 0.00^{\mathrm{d}}$ & $2.78 \pm 0.02^{\mathrm{a}}$ & $164.67 \pm 0.43^{\mathrm{a}}$ & $0.49 \pm 0.00^{\mathrm{d}}$ & $1.24 \pm 0.02^{\mathrm{e}}$ & $96.67 \pm 3.33$ \\
\hline $\mathbf{W}_{1} * \mathbf{T}_{3}$ & $3.62 \pm 0.04$ & $31.72 \pm 0.23^{\mathrm{e}}$ & $0.33 \pm 0.00^{\mathrm{e}}$ & $2.58 \pm 0.01^{\mathrm{a}}$ & $159.03 \pm 0.31^{\mathrm{b}}$ & $0.46 \pm 0.01^{\mathrm{e}}$ & $1.37 \pm 0.02^{\mathrm{d}}$ & $90.00 \pm 5.77$ \\
\hline $\mathbf{W}_{2} * \mathbf{T}_{1}$ & $35.36 \pm 0.11$ & $71.14 \pm 0.64^{\mathrm{c}}$ & $0.43 \pm 0.01^{\mathrm{c}}$ & $0.83 \pm 0.01^{\mathrm{d}}$ & $67.19 \pm 0.91^{\mathrm{e}}$ & $1.39 \pm 0.01^{\mathrm{c}}$ & $3.28 \pm 0.07^{\mathrm{a}}$ & $100.00 \pm 0.00$ \\
\hline $\mathbf{W}_{2} * \mathbf{T}_{2}$ & $35.19 \pm 0.09$ & $85.84 \pm 0.57^{\mathrm{a}}$ & $0.60 \pm 0.01^{\mathrm{a}}$ & $1.06 \pm 0.01^{\mathrm{c}}$ & $83.70 \pm 0.66^{\mathrm{d}}$ & $1.56 \pm 0.01^{\mathrm{a}}$ & $2.59 \pm 0.04^{\mathrm{b}}$ & $96.67 \pm 3.33$ \\
\hline $\mathbf{W}_{2} * \mathbf{T}_{3}$ & $35.25 \pm 0.11$ & $81.49 \pm 0.46^{\mathrm{b}}$ & $0.55 \pm 0.01^{\mathrm{b}}$ & $1.00 \pm 0.01^{\mathrm{c}}$ & $79.20 \pm 0.58^{\mathrm{d}}$ & $1.49 \pm 0.01^{\mathrm{b}}$ & $2.71 \pm 0.03^{b}$ & $100.00 \pm 0.00$ \\
\hline Significance & NS & $* * *$ & $* *$ & $* * *$ & $* *$ & $* * *$ & $* * *$ & NS \\
\hline
\end{tabular}

Means in the same rows within each classification having different superscript letters were significantly different at $\mathrm{P}<0.05$.

$\mathrm{W}_{1}=$ Low stocking weight, $\mathrm{W}_{2}=$ High stocking weight, $\mathrm{T}_{1}=$ Control, $\mathrm{T}_{2}=0.5 \mathrm{~g}$ powertop ${ }^{\circledR}$ and $\mathrm{T}_{3}=1.0 \mathrm{~g}$ powertop ${ }^{\circledR}$.

Lara- Flores et al. (2003) found that the fry fed diets supplemented with a probiotic exhibited greater growth than those fed the control diet. Also, significant improvements in growth rate and feed efficiency were observed in all indices of growth with using probiotic biogen supplementation as a growth promoter for Nile tilapia Oreochromis niloticus (El-Haroun et al., 2006). In contrast, Hidalgo et al. (2006) found that growth and feed conversion of juvenile dentex were not significantly influenced by probiotics. Improving the feed intake in the current study may be due to bactericidal effects which increases the palatability of feed and stimulates the appetite.

This may be due to the effect of the tested probiotics which improved absorption of nutrients and depressed harmful bacteria which may causes growth depression. The pervious results are in agreement with those obtained by Hoyos and Cruz (1990) who stated that the positive effect of probiotcs may be due to their beneficial effects since its microbial constituents produce natural lactic acid that helps in maintaining an optimum low $\mathrm{pH}$ in the digestive tract which inhibits growth of undesirable bacteria leading to optimum enzyme activity. Also, Probiotices can enhance the metabolism and energy of fish body cells, raising the efficiency of feed utilization and balance the secretion of various secretory glands. Moreover, it increases the vitality of cells by supplying oxygen to whole body, improves the immune responses, helps to excrete heavy metals, inhibits aflatoxin and maintains the normal functions of the endocrine system.

\section{Blood components:}

Effect of fish stocking weight and powertop ${ }^{\circledR}$ supplementation and their interactions on blood components of Nile tilapia is presented in Table 3 . Current results explain that, ALT, RBC and $\mathrm{HB}$ are affected significantly with stocking weight, while other blood components were insignificantly affected by the stocking weight.

Blood total protein and its fractions were insignificantly affected by powertop ${ }^{\circledR}$ supplementation, while other blood parameters were affected significantly $(\mathrm{P}<0.01)$. The highest value for blood albumin was recorded by fingerlings fish with $1 \mathrm{~g}$ powertop $\AA / \mathrm{kg}$ diet. Blood concentration of ALT enzyme was significantly $(\mathrm{P}<0.01)$ affected by initial body weight but not for blood AST concentration. Powertop ${ }^{\circledR}$ supplementation significantly $(\mathrm{P}<0.01)$ affected both of alanine aminotransferase enzyme and Aspartate aminotransferase concentrations. 
Table 3. Effect of fish initial body weight, Powertop ${ }^{\circledR}$ treatment and their interaction on blood components of Nile tilapia

\begin{tabular}{|c|c|c|c|c|c|c|c|c|}
\hline Items & $\begin{array}{l}\text { Total protein, } \\
\text { TP (g/dl) }\end{array}$ & $\begin{array}{l}\text { Albumin, } \\
\text { ALB(g/dl) }\end{array}$ & $\begin{array}{l}\text { Globulin, } \\
\text { GLB(g/dl) }\end{array}$ & $\operatorname{AST}(\mathbf{U} / \mathbf{d l})$ & ALT(U/dl) & $\begin{array}{c}\text { TWBC } \\
\left(10^{6} \mathrm{~mm}-3\right)\end{array}$ & $\begin{array}{c}\text { TRBC } \\
\left(10^{6} \mathrm{~mm}-\right. \\
3)\end{array}$ & Hb (\%) \\
\hline \multicolumn{9}{|c|}{ Effect of fish stocking weight } \\
\hline $\begin{array}{l}\text { Low stocking } \\
\text { weight }\left(\mathrm{W}_{1}\right)\end{array}$ & $5.35 \pm 0.13$ & $2.88 \pm 0.07$ & $2.47 \pm 0.10$ & $32.75 \pm 1.32$ & $17.09 \pm 0.39$ & $22.66 \pm 0.44$ & $3.62 \pm 0.10$ & $6.07 \pm 0.08$ \\
\hline $\begin{array}{l}\text { High stocking } \\
\text { weight }\left(\mathrm{W}_{2}\right)\end{array}$ & $5.12 \pm 0.19$ & $2.67 \pm 0.17$ & $2.45 \pm 0.17$ & $32.28 \pm 2.50$ & $15.65 \pm 0.53$ & $22.79 \pm 0.58$ & $3.08 \pm 0.15$ & $4.77 \pm 0.17$ \\
\hline Significance & NS & NS & NS & NS & $* *$ & NS & $* *$ & $* *$ \\
\hline \multicolumn{9}{|c|}{ Effect of dietary probiotic supplementation } \\
\hline Control $\left(\mathrm{T}_{1}\right)$ & $5.42 \pm 0.21$ & $2.71 \pm 0.14$ & $2.71 \pm 0.13$ & $27.25 \pm 2.01^{\mathrm{b}}$ & $14.81 \pm 0.58^{\mathrm{b}}$ & $20.88 \pm 0.21^{\mathrm{c}}$ & $2.90 \pm 0.18^{\mathrm{c}}$ & $5.78 \pm 0.27^{\mathrm{a}}$ \\
\hline $\begin{array}{l}0.5 \text { g powertop } \AA \\
\left(T_{2}\right)\end{array}$ & $5.33 \pm 0.11$ & $2.93 \pm 0.21$ & $2.40 \pm 0.13$ & $34.85 \pm 0.88^{\mathrm{a}}$ & $17.16 \pm 0.31^{\mathrm{a}}$ & $23.25 \pm 0.32^{\mathrm{b}}$ & $3.48 \pm 0.11^{\mathrm{b}}$ & $5.19 \pm 0.38^{b}$ \\
\hline $\begin{array}{l}1.0 \text { g powertop }{ }^{\circledR} \\
\left(\mathrm{T}_{3}\right)\end{array}$ & $4.97 \pm 0.23$ & $2.70 \pm 0.15$ & $2.27 \pm 0.20$ & $35.46 \pm 2.44^{\mathrm{a}}$ & $17.14 \pm 0.42^{\mathrm{a}}$ & $24.03 \pm 0.11^{\mathrm{a}}$ & $3.68 \pm 0.12^{\mathrm{a}}$ & $5.29 \pm 0.29^{\mathrm{b}}$ \\
\hline Significance & NS & NS & NS & $* *$ & $* *$ & $* *$ & $* *$ & $*$ \\
\hline \multicolumn{9}{|c|}{ The interaction effect of stocking weight and dietary probiotic supplementation } \\
\hline $\mathbf{W}_{1} * \mathbf{T}_{1}$ & $5.72 \pm 0.06$ & $3.01 \pm 0.05^{\mathrm{a}}$ & $2.72 \pm 0.00$ & $31.45 \pm 1.62^{\mathrm{c}}$ & $15.88 \pm 0.36$ & $21.10 \pm 0.31$ & $3.30 \pm 0.06$ & $6.28 \pm 0.05$ \\
\hline $\mathbf{W}_{1} * \mathbf{T}_{2}$ & $5.13 \pm 0.10$ & $2.61 \pm 0.05^{b}$ & $2.52 \pm 0.05$ & $35.45 \pm 1.71^{\mathrm{b}}$ & $17.48 \pm 0.56$ & $22.93 \pm 0.30$ & $3.70 \pm 0.06$ & $6.01 \pm 0.11$ \\
\hline $\mathbf{W}_{1} * \mathbf{T}_{3}$ & $5.21 \pm 0.28$ & $3.03 \pm 0.07^{\mathrm{a}}$ & $2.18 \pm 0.21$ & $31.35 \pm 3.15^{\mathrm{c}}$ & $17.93 \pm 0.42$ & $23.93 \pm 0.22$ & $3.87 \pm 0.18$ & $5.92 \pm 0.16$ \\
\hline $\mathbf{W}_{2} * \mathbf{T}_{1}$ & $5.12 \pm 0.35$ & $2.41 \pm 0.07^{\mathrm{b}}$ & $2.71 \pm 0.28$ & $23.05 \pm 0.26^{\mathrm{d}}$ & $13.75 \pm 0.64$ & $20.67 \pm 0.27$ & $2.50 \pm 0.06$ & $5.28 \pm 0.32$ \\
\hline $\mathbf{W}_{2} * \mathbf{T}_{2}$ & $5.53 \pm 0.07$ & $3.25 \pm 0.33^{\mathrm{a}}$ & $2.28 \pm 0.25$ & $34.25 \pm 0.78^{\mathrm{b}}$ & $16.85 \pm 0.32$ & $23.57 \pm 0.58$ & $3.25 \pm 0.09$ & $4.37 \pm 0.21$ \\
\hline $\mathbf{W}_{2} * \mathbf{T}_{3}$ & $4.73 \pm 0.36$ & $2.36 \pm 0.01^{\mathrm{b}}$ & $2.37 \pm 0.37$ & $39.56 \pm 1.76^{\mathrm{a}}$ & $16.35 \pm 0.29$ & $24.13 \pm 0.03$ & $3.50 \pm 0.06$ & $4.67 \pm 0.08$ \\
\hline Significance & NS & $* *$ & NS & $* *$ & NS & NS & NS & NS \\
\hline
\end{tabular}

Means in the same rows having different superscript letters were significantly different at 0.05 levels.

$\mathrm{W}_{1}=$ Low stocking weight, $\mathrm{W}_{2}=$ High stocking weight, $\mathrm{T}_{1}=$ Control, $\mathrm{T}_{2}=0.5$ g powertop $\AA$ and $\mathrm{T}_{3}=1.0 \mathrm{~g}$ powertop ${ }$.

Moreover, the interaction between fish stocking weight and powertop ${ }^{\circledR}$ supplementation affected significantly $(\mathrm{P}<0.01)$ blood concentration of AST and albumin, while other blood components were insignificantly affected. Mohamed (2007) revealed an increase in plasma total protein of $O$. niloticus fingerlings fed on probiotic and yeast. Measurement of globulin is of considerable diagnostic procedure in experimental animals as it relates to general nutritional status, the integrity of the vascular system, and liver functions. High blood albumin concentration may be due to an increase of protein synthesis, or a decrease catabolism (Nguyen et al., 1999). Moreover, there were no harmful effects on liver functions by probiotic treatment, initial body weight and their interaction. Compared to control serum level, transferase enzymes (ALT and AST) were decreased significantly with fingerlings than fry fish. These results indicate that fish fingerlings may utilize the experimental diets with powertop ${ }^{\circledR}$ more than fish fry and therefore improved liver functions. The pervious results were in agreement with estimating hematological procedures contained TRBC, TWBC count and $\mathrm{Hb}$ percentage. Hematological parameters were improved by probiotic treatment especially with fingerlings fish but this improvement was lower with their interaction. Current results are close to the results of Mohsen et al. (2010) who categorized experimental fish into three weights; $0.4-0.5 \mathrm{~g}$ (fry), $17-22 \mathrm{~g}$ (fingerling), and 37-43 g (advanced juvenile) and fed them on diets containing 45,35 , or $25 \%$ crude protein. Beside, activities of aspartate amninotransferase (AST) and alanine aminotransferase (ALT) in serum, liver, and muscles were significantly affected by dietary protein level and fish weight. While, the interaction between fish weight and supplemental protein levels had no significant effect except for serum AST level.

\section{Fish Body Composition:}

Results in Table 3 explain that stocking weight had no significant influence on whole fish body composition. The same trend of insignificant effect was observed with powertop ${ }^{\circledR}$ supplementation and its interaction with stocking weight on dry matter, crude protein and ash content of whole body components. In contrast, powertop ${ }^{\circledR}$ supplementation and its interaction with stocking weight affected significantly $(\mathrm{P}<0.05)$ on ether extract. High ether extract content was obtained by interaction of stocking weight and powertop ${ }^{\circledR}$ supplementation at $0.5 \mathrm{~g} / \mathrm{kg}$ diet.

Jamali et al. (2014) fed probiotic bacteria (Lactobacillus sp., Bifidobacterium sp. and Streptococcus $s p$.) to rainbow trout larvae and found that, protein values of carcass in all probiotic treated groups were significantly $(\mathrm{p}<0.05)$ higher than other experimental groups. Also, crude lipid, ash and gross energy of the experimental probiotic fish groups differed significantly compared to the other fish treatment groups.

\section{Profit Analysis:}

Return from body gain and feed cost was increased in fish group reared at high initial body weight, while final profit was decreased (Table 4). 
Feed cost, return from body gain and final profit were improved in fish groups treated with powertop ${ }^{\circledR}$. The return from body gain was increased by 72.9 and $52.1 \%$ in fish fed diets supplemented with 0.5 and 1.0 g powertop $\AA / \mathrm{kg}$ diet, respectively. Also, the same trend for the final margin was 154.8 and $91.4 \%$, respectively.

Table 4. Effect of fish initial body weight, Powertop ${ }^{\circledR}$ treatment and their interaction on fish body components

\begin{tabular}{|c|c|c|c|c|}
\hline Items & $\begin{array}{c}\text { Dry } \\
\text { matter \% }\end{array}$ & Crude protein \% & Ether extract \% & Ash \% \\
\hline \multicolumn{5}{|l|}{ Effect of fish stocking weight } \\
\hline Low stocking weight $\left(\mathrm{W}_{1}\right)$ & $24.75 \pm 0.22$ & $61.47 \pm 0.41$ & $12.53 \pm 0.31$ & $10.94 \pm 0.18$ \\
\hline High stocking weight $\left(\mathrm{W}_{2}\right)$ & $24.58 \pm 0.13$ & $62.58 \pm 0.37$ & $12.35 \pm 0.20$ & $10.61 \pm 0.10$ \\
\hline Significance & NS & NS & NS & NS \\
\hline \multicolumn{5}{|c|}{ Effect of dietary probiotic supplementation } \\
\hline Control $\left(\mathrm{T}_{1}\right)$ & $24.88 \pm 0.23$ & $61.73 \pm 0.60$ & $12.59 \pm 0.34^{\mathrm{a}}$ & $10.66 \pm 0.14$ \\
\hline 0.5 g powertop ${ }^{\circledR}\left(\mathrm{T}_{2}\right)$ & $24.76 \pm 0.22$ & $61.87 \pm 0.35$ & $12.93 \pm 0.22^{\mathrm{a}}$ & $10.69 \pm 0.15$ \\
\hline 1.0 g powertop ${ }^{\circledR}\left(\mathrm{T}_{3}\right)$ & $24.35 \pm 0.15$ & $62.49 \pm 0.61$ & $11.80 \pm 0.21^{\mathrm{b}}$ & $10.98 \pm 0.26$ \\
\hline Significance & NS & NS & $*$ & NS \\
\hline \multicolumn{5}{|c|}{ The interaction effect of stocking weight and dietary probiotic supplementation } \\
\hline $\mathrm{W}_{1} * \mathrm{~T}_{1}$ & $25.24 \pm 0.33$ & $61.55 \pm 0.89$ & $12.96 \pm 0.24^{\mathrm{a}}$ & $10.83 \pm 0.24$ \\
\hline $\mathbf{W}_{1} * \mathbf{T}_{2}$ & $24.70 \pm 0.47$ & $61.40 \pm 0.60$ & $13.28 \pm 0.21^{\mathrm{a}}$ & $10.99 \pm 0.09$ \\
\hline $\mathbf{W}_{1} * \mathbf{T}_{3}$ & $24.31 \pm 0.18$ & $61.47 \pm 0.91$ & $11.34 \pm 0.05^{\mathrm{c}}$ & $11.01 \pm 0.57$ \\
\hline $\mathbf{W}_{2} * \mathbf{T}_{1}$ & $24.53 \pm 0.19$ & $61.91 \pm 0.98$ & $12.22 \pm 0.62^{\mathrm{b}}$ & $10.50 \pm 0.10$ \\
\hline $\mathbf{W}_{2} * \mathbf{T}_{2}$ & $24.83 \pm 0.16$ & $62.35 \pm 0.19$ & $12.58 \pm 0.26^{\mathrm{ab}}$ & $10.39 \pm 0.14$ \\
\hline $\mathbf{W}_{2} * \mathbf{T}_{3}$ & $24.39 \pm 0.28$ & $63.50 \pm 0.04$ & $12.26 \pm 0.12^{b}$ & $10.95 \pm 0.11$ \\
\hline Significance & NS & NS & * & NS \\
\hline
\end{tabular}

Means in the same rows having different superscript letters were significantly different at 0.05 levels.

$\mathrm{W}_{1}=$ Low stocking weight, $\mathrm{W}_{2}=$ High stocking weight, $\mathrm{T}_{1}=$ Control, $\mathrm{T}_{2}=0.5 \mathrm{~g}$ powertop ${ }^{\circledR}$ and $\mathrm{T}_{3}=1.0 \mathrm{~g}$ powertop ${ }^{\circledR}$.

Table 5. Effect of fish initial body weight, Powertop® treatment and their interaction on economic evaluation

Items $\begin{gathered}\text { Feed } \\ \text { cost } \\ (\mathrm{LE} / \text { fish })\end{gathered} \quad$ Return from gain (LE/fish) $\quad$ Margin (LE/fish) $\quad$ Margin efficiency (LE/fish)

Effect of fish stocking weight

Low stocking

weight $\left(\mathrm{W}_{1}\right)$

High stocking

weight $\left(\mathrm{W}_{2}\right)$

0.155

0.388

0.233

0.215

0.510

0.623

0.114

0.112

Effect of dietary probiotic supplementation

$\begin{array}{lllll}\text { Control }\left(\mathrm{T}_{1)}\right. & 0.307 & 0.340 & 0.093 & 0.089 \\ \begin{array}{l}0.5 \mathrm{~g} \\ \text { powertop }{ }^{\circledR}\left(\mathrm{T}_{2}\right)\end{array} & 0.351 & 0.588 & 0.237 & 0.229 \\ \begin{array}{l}1.0 \mathrm{~g} \\ \text { powertop }{ }^{\circledR}\left(\mathrm{T}_{3}\right)\end{array} & 0.338 & 0.517 & 0.178 & 0.171\end{array}$

The interaction effect of stocking weight and dietary probiotic supplementation

$\begin{array}{lllll}\mathbf{W}_{\mathbf{1}} * \mathbf{T}_{\mathbf{1}} & 0.134 & 0.306 & 0.171 & 0.154 \\ \mathbf{W}_{\mathbf{1}} * \mathbf{T}_{\mathbf{2}} & 0.169 & 0.459 & 0.290 & 0.280 \\ \mathbf{W}_{\mathbf{1}} * \mathbf{T}_{\mathbf{3}} & 0.158 & 0.388 & 0.230 & 0.207 \\ \mathbf{W}_{\mathbf{2}} * \mathbf{T}_{\mathbf{1}} & 0.479 & 0.506 & 0.027 & 0.027 \\ \mathbf{W}_{\mathbf{2}} * \mathbf{T}_{\mathbf{2}} & 0.537 & 0.706 & 0.168 & 0.163 \\ \mathbf{W}_{\mathbf{2}} * \mathbf{T}_{\mathbf{3}} & 0.513 & 0.647 & 0.134 & 0.134\end{array}$

$\mathrm{W}_{1}=$ Low stocking weight, $\mathrm{W}_{2}=$ High stocking weight, $\mathrm{T}_{1}=$ Control, $\mathrm{T}_{2}=0.5 \mathrm{~g}$ powertop ${ }^{\circledR}$ and $\mathrm{T}_{3}=1.0 \mathrm{~g}$ powertop ${ }^{\circledR}$. 
Within each stocking weight, feed cost, return from body gain and final profit were increased in fish groups treated with powertop ${ }^{\circledR}$. Higher return from body gain and final profit were obtained in fish group fed diet supplemented with $0.5 \mathrm{~g}$ powertop $\AA$ and reared at low stocking weight.

\section{CONCLUSION}

The current data explain that, powertop $\AA$ probiotic improved the growth performance, carcass parameters and some blood motilities. Therefore, it can be used as growth promoters in Tilapia fry and fingerlings.

\section{REFERENCES}

AOAC, 1995. Official Methods of Analysis of the Association of Official Analytical Chemists, $14^{\text {th }}$. AOAC, Arlington, 3413 pp.

Ayyat M.S., M. Howaida M. Labib and Hemat K. Mahmoud, 2014. A Probiotic Cocktail as a Growth Promoter in Nile Tilapia (Oreochromis niloticus), Journal of Applied Aquaculture, 26:3, 208-215.

Ayyat, M.S., 1991. Growth and carcass production of growing rabbits as affected by dietary energy level. Zagazig J. Agric. Res., 18: 109-122.

Berger, A. and J. E. Halver, 1987. Effect of dietary protein, lipid and carbohydrate content on the growth, feed efficiency and carcass composition of Striped bass, (Morone saxatitis W.) fingerlings. Aquaculture, 18: 345 -356.

Boyd, C.E., 1990. Water quality in ponds for aquaculture. Bermingham Publishing Co., Bermingham, Alabama, USA.

Burgents, J.E., B. Burnett and K.G.,Burnett, L.E., 2004. Diseases resistance of pacific white shrimp, Litopenaeus vannamei, following the dietary dministration of a yeast culture food supplement, Aquaculture 31 (1-6).

Chen, J. and R. Seviour, 2007. Medicinal importance of fungal beta-(1/3), (1/6)- glucans. Mycol Res; 111:635e52.

Dalmo, R. A. and R. Seljelid, 1995. The immunomodulatory effect of LPS, laminaran and

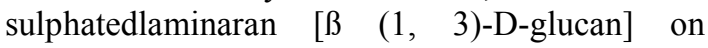
Atlantic salmon, Salamosalar L., macrophages in vitro. J. of Fish Diseases. 18, 175-185.

Dalmo, R. and J.Bøgwald, 2008. ß -glucans as conductors of immune symphonies. Fish \& Shellfish Immunology; 25:384e96.

Duncan, M.B., 1955. Multiple ranges and multiple Ftests. Biometrics, 11:1-42.

El-Haroun, E.R., A.M. Goda, and M.A. KabirChowdhury, 2006. Effect of dietary probiotic biogen supplementation as a growth promoter on growth performance and feed utilization of Nile tilapia Oreochromi sniloticus (L.), Aquaculture Research 37 (14) 1473-1480.
Fagbenro, O. A. and E. A. Fasakin, 1996. Citric-acidensiled poultry viscera as protein supplement for catfish (Clariagariepinus). Bioresource Technology, v. 58, n. 1, p. 13-16.

Gao, Y., K. V. Lo and P. H. Liao, 1992. Utilization of salmon farm mortalities: fish silage. Bioresource Technology, v. 41, n. 2, p. 123-127.

Gatesoupe, F. J., 1999. The use of probiotics in aquaculture. Aquaculture, 191, 147-165.

Guselle, N. J., Markham and D. J. Speare, 2007. Timing of intraperitoneal administration of $\beta$ 1,3/1,6 glucan to rainbow trout, Oncorhynchus mykiss (Walbaum), affects protection against the microsporidian Loma salmonae. J. of Fish Diseases, 30(2):111 - 116.

Hidalgo, M.c., A. Skalli, E. Abellan, M. Arizcum and G. Gardenete, 2006. Dietary intake of probiotics and maslinic acid in Juvenile dentex (Dentexdentex L.). Effects on growth performance, survival and liver proteolyticactivies. Aqua. Nutrition Vo. 12(4): 256-266.

Hoyos, A.G. and C. Cruz, 1990. Mecanismos de accionpropuestas de la probiotics en cedes: biotechnology en la inductria de Alimentacion Animal., 1: 73-80.

Jain, N.C., 1993. Essential of veterinary hematology. copyrights by Lea and Febiger Philadelphia, USA.

Jamali, H., H. Moghadam, N. Pariche and H. Jafaryan, 2014.Effects of probiotic bacteria on survival, growth and body composition of rainbow trout (Oncorhynchusmykiss) larvae fed diets with various fish meal.Journal of Coastal Life Medicine 2015; 3(2): 91-97.

Kumari, J. and P. K. Sahoo, 2006. Dietary â-1,3 glucan potentiates innate immunity and disease resistance of Asian catfish, Clariasbatrachus (L.). J. of Fish Diseases, volume 29 (1) 95.

Laird, L. and T. Needham, 1988. Salmon and trout farming. Harwood, New York.

Lara-Flores, M. and G. Aguirre-Guzman, 2009. The use of probiotic in fish and shrimp aquaculture.A review. In: Perez-Guerra N. \&Pastrana-Castro L. (Eds), Probiotics: Production, evaluation and uses in animal feed (pp. 75-89). Kerala: Research Signpost.

Lara-Flores, M., M.A. Olvera-Novoa, B. E. GuzmanMendez, and W. Lopez-Madrid, 2003. Use of the bacteria Streptococcus faecium and Lactobacillus acidophilus, and the yeast Saccharomyces cerevisiae as growth promoters in Nile tilapia (Oreochromis niloticus). Aquaculture, 216: 193201.

Lauridsen J.H. and K. Buchmann. 2010. Effects of short- and long-tern glucan feeding of rainbow trout (Salmonidae) in the susceptibility of chthyophthirius multifiliis infection. Acta ichthyol piscat; 40:61 e6

Maurilio L., A.O. Miguel, E.G. Beatriz and L. Wilberth, 2002. Use of the bacteria Streptococcus 
faecium and Lactobacillus acidophilus, and the yeast Saccharomyces cerevisiae as growth promoters in Nile tilapia (Oreochromisniloticus). Aquaculture, 216:193-201.

Mohamed, K.A., 2007. Effect of using probiotic and yeast as growth promoters in commercial diet of tilapia (Oreochromisniloticus) fingerlings. Agricultural Research Journal, Suez Canal University, 7: 41-47.

Mohsen, A., H. A. Mohammad, A.E. K.Yassir and M.E. S. Adel, 2010. Effect of dietary protein level, initial body weight, and their interaction on the growth, feed utilization, and physiological alterations of Nile tilapia, Oreochromis niloticus (L.) . Aquaculture, 298( 3-4): 267-274.

Morales-Ulloa, D. F. and M. Oetterer, 1995. Bioconversão de resíduos da indústriapesqueira. Ciência e Tecnologia de Alimentos, v. 15, n. 3, p. 206-214.

Nguyen, H.T., W. F. Loeb, and F.W. Quimby, 1999. The Clinical Chemistry of Laboratory Animals, Second Edition. Taylor and Francis, Philadelphia, PA, USA, pp 309 - 335.

NRC, 2011. Nutrient requirements of fish and shrimp. Animal Nutrition Series National Research Council of the National Academies. The National Academies Press, Washing-ton, D.C., USA (376 pp

Ringø, E. and F. J.Gatesoupe, 1998. Lactic acid bacteria in fish: a review. Aquaculture, 160, 177203.

Rodriguez, I., R. Chamorro, B. Novoa, A. Figueras, 2009. B-Glucan administration enhances disease resistance and some innate immune responses in zebrafish (Daniorerio). Fish\&Shellfish Immunology. 27:369e73.

Salminen, S., A. V. Wright and A. Ouwehad, 2004. Lactic acid bacteria (Vol. 1).New York:Marcel Dekker Inc.

SAS, 2002. SAS Institute Inc., Cary, NC, USA. NOTE: SAS Proprietary Software Version 9.00 (TS M0).

Snedecor, G.W. and W.G. Cochran,1982. Statistical Methods. $7^{\text {th }}$ ed. Iowa stat Univ. Press. Ames. Iowa, U.S.A.

Stoskopf, M.K., 1993. Fish Medicine. pp. 113-131. Edited by M. K. Stoskopf. Saunders, Philadelphia.

Tietz, N.W., 1990. Clinical Guide to Laboratory Tests 2nd Ed. Philadelphia.

Tovar, D., J. C. Zambonino Ahu, F.J. Gatesoupe, , R. Vázquez-Juárez, R. Lésel, 2002. Effect of live yeast incorporation in compound diet on digestive enzyme activity in sea bass (Dicentrarchus labrax) Larvae, Aquaculture 204 :113-123.

Vine, N.G., W.D. Leukes, H. Kaiser, S. Daya, J. Baxter and T. Hecht, 2004. Competition for attachment of aquaculture candidate probiotic and pathogenic bacteria on fish intestinal mucus. J. Fish Dis. 27:319-326.

Young, D.S., 1990. Effects of drugs on clinical laboratory tests. Third Edition,AACC Press, Washington, D.C. 32(3):30-33.

ZAR, J.H., 1984.Biostatistical analysis. Prentice-Hall Inc., Englewood Clifffs, New Jersey.

\section{تقييم الباورتوب كمحن نمو لاصبعيات البلطى النيلى فى اوزان تربية مختلفة

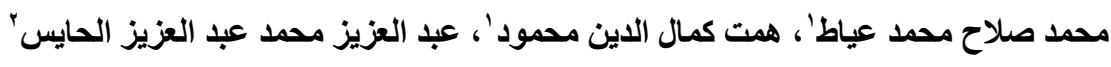 | ـ قسم الاتتاج الحيوانى، كلية الزراعة، جامعة الزقازيق، r ـ فسم الإتتاج الحيوانى، كلية الزراعة، جامعة طنطا}

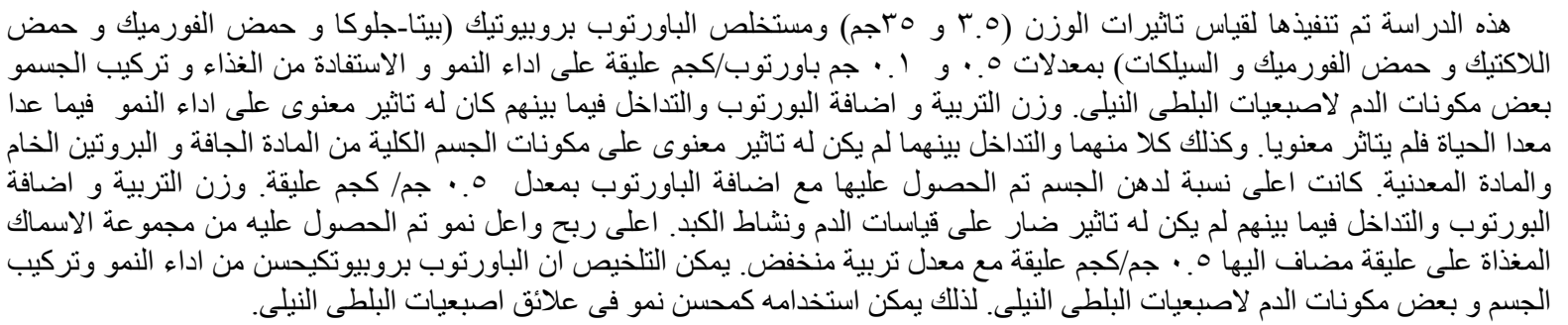

